\title{
Kompetence vysokoškolských učitelů pro udržitelný rozvoj - analýza situace $v$ regionu střední a východní Evropy
}

\author{
Jana Dlouhá, Jiří Dlouhý \\ Envigogika 10 (3) - Recenzované články/Reviewed articles
}

Publikováno/Published dne 29. 12. 2015

DOI: $10.14712 / 18023061.507$

\begin{abstract}
Abstrakt
Pro rozvoj oborů souvisejících s udržitelným rozvojem na vysokoškolské úrovni jsou zapotřebí především změny $v$ samotné výuce. Aby poukázali na procesy související $s$ touto transformací, zkoumali autoři (předpoklady pro) rozvoj kompetencí vysokoškolských pedagogů ve 13 zemích střední a východní Evropy a srovnali tato zjištění s podobnými poznatky z jiných evropských zemí. Pro analýzu situace byl využit průzkum, v němž byly zjištóvány národní podmínky pro VUR na úrovni VŠ; samotné kompetence pak byly vybrány z príkladů dobré praxe $v$ prípadových studiích, vypracovaných podle vzoru kompetencí EHK OSN. Výsledky ukazují některé nedostatky v profesním rozvoji vysokoškolských pedagogů: pěstování kompetencí není obecně věnována pozornost a chybí zvláště v oblasti VUR. $V$ důsledku toho jsou př́stupy a principy VUR aplikovány ve zkoumané části světa méně často.

Z širšího pohledu vyplývá, že přiležitosti pro rozvoj kompetencí na úrovni vš existují, ale jsou nerovnoměrně rozděleny mezi jednotlivými zeměmi. Pro podporu profesního rozvoje kompetencí vysokoškolských pedagogů v oblasti VUR je důležitým faktorem pochopení environmentálního vzdělávání ve vztahu k vzdělávání pro udržitelný rozvoj, a také přijetí inter- či trans-disciplinární perspektivy. Autoři tvrdí, že oborový př́stup je hluboce zakořeněnou součástí akademické kultury ve všech post-socialistických zemích střední a východní Evropy, zatímco pro udržitelnost je zásadní transdisciplinární přístup a širší zapojení zúčastněných stran. Kontext prezentovaného výzkumu tvoří projekt University Educators for Sustainable Development (UE4SD), do kterého je zapojeno 53 partnerů z 33 evropských zemí; jejich spolupráce má pomoci určit nejlepší způsoby, jak rozvíjet kompetence vysokoškolských pedagogů ve výuce udržitelnosti. Některé výsledky tohoto projektu jsou v článku stručně představeny.
\end{abstract}

\section{Klíčová slova:} vzdělávání

Vysoké školy; kompetence; udržitelný rozvoj; východní Evropa; změna systému

\section{Abstract}

Debates relevant to sustainability oriented teaching at higher education level anticipate the necessary transitions in curricula. In order to depict the overall ESD related transformation of university teaching, the authors examined (pre-requisites for the develop- 
ment of) university educators' competences in 13 countries of the Central and Eastern Europe, and compared these findings with those from other European countries (similar in some aspects). The situation was analysed in a survey where national policy conditions for ESD at HE level were examined, and competences were outlined within good practice case studies according to the UNECE framework. The results show some deficits in professional development of university educators, where attention to competences is missing in general, and in the field of ESD in particular. In consequence, ESD approaches and principles are applied less frequently in this part of Europe.

From a broader point of view it was observed that opportunities for competence development at HE level exist but are unevenly distributed across countries. For support of professional development of university educators in the field of ESD competences, understanding of environmental education versus ESD is an important factor, and also acceptance of an inter- or transdisciplinary perspective. The authors argue that disciplinarianism is a deeply rooted part of academic culture in all post-socialist CEE countries, while for sustainability a transdisciplinary approach and the wider involvement of stakeholders is crucially needed. The context of the presented research is the University Educators for Sustainable Development (UE4SD) project where 53 partners from 33 European countries collaborate to identify the best ways to develop university educators' competences in sustainability teaching. The outcomes of this project are briefly introduced in the article.

\section{Key words:}

Higher education; competences; sustainable development; Eastern Europe; educational transition 


\section{Úvod}

Ačkoli se rozdíl mezi environmentálním vzděláváním a vzděláváním pro udržitelný rozvoj (VUR) někdy chápe jako poměrně zásadní: spočívající v rozporu mezi ekocentrickým (environmentální, ekologický) a na druhé straně antropocentrickým přístupem (udržitelný rozvoj), což omezuje schopnost druhého efektivně řešit člověkem zpưsobené škody na životním prostředí (srv. Kopnina, 2012), autoři tohoto článku jej vidí spíše vycházet z vývojových stadií téhož př́stupu. Koncept udržitelnosti (ve vzdělávání) nezbytně pracuje $\checkmark$ daleko větší míře $s$ většinovým názorem, protože má ambice stát se přístupem sdíleným většinou společnosti (a jejích vzdělávacích systémů). Hledisko ochrany životodárných ekosystémů i jednotlivých druhů mimolidského života je $v$ něm nadále silné, mělo by být ale dopIněno o sociální hlediska, a pluralitní, kritické, svobodné přistupy ve vzdělání, které umožňují společné vytváření znalostí spolu se soustavnou reflexí jejich základů (Wals, 2010). Tento typ vzdělání pak může překonat různé kulturní rozdíly a místní specifika, a jako takový je též prosazován na mezinárodní úrovni (UNECE, 2005). Nicméně environmentální vzdělání je zde současně pokládáno za vývojově starší koncept, jehož rolí nebylo mít takto zásadní dopad na celkovou změnu vzdělávacích systémů (vůči nim se spíše vymezovalo), současně však si kladlo vedle praktických, instrumentálně dosažitelných cílů v ochraně př́rody a jejích zdrojů za cíl také změnu smýšlení a lidských hodnot. Ve vzdělání pro udržitelný rozvoj jsou tyto principy přítomny také, projevují se však požadavkem na rozvíjení širokého spektra dovedností (kompetencí) potřebných pro realizaci změn k udržitelnosti v různých oblastech.

Obecně platí, že "ve vzdělávání pro udržitelný rozvoj mohou hrát významnou roli vysoké školy, protože mohou propojit regiony, překlenout hranice oborů či zprostředkovat vazby mezi místní a globální dimenzí udržitelného rozvoje. Jsou uznávány pro svůj vliv ve společnosti i prímo na politiku, pưsobí ovšem i nepř́mo, a to prostřednictvím vzdělávání budoucích politiků. Ovlivňují výchovu vůdčích osobností a také historické dění." (COPERNICUS Alliance, 2013, s. 2). Pro naplnění této své společenské úlohy by ovšem měly i vysoké školy samotné projít určitou transformací; a tyto změny by měly hluboce proměnit především proces vzdělávání jako takový.

\section{Tradice a možnosti změn ve vzdělávání na vysokých školách smě- rem $k$ VUR}

V rámci Dekády vzdělávání pro udržitelný rozvoj (DESD) bylo často zdůrazňováno, že vysokoškolské instituce mohou významně přispět $k$ udržitelnému rozvoji; $k$ tomu by však měly zaujmout více holistický (celostní) přístup, to znamená propojovat všechny oblasti svého působení (Sibbel, 2009; Sterling, Maxey, \& Luna, 2013). Měly by tak přijmout celoinstitucionální strategie "ozelenění" (Lukman, Krajnc, \& Glavič, 2010) které by nahradily často roztříštěné koncepce současného fungování (Lozano et al., 2015). Hlubší proměny na institucionální úrovni by tak mělo být dosaženo v "dynamické rovnováze" různých strukturních prvků (Waas et al., 2012).Této celkové změny je na vysokoškolské úrovni poměrně těžké dosáhnout; její obecné zásady a představy o procesech s ní spojených předkládá Úmluva o vysokých školách vytvořená u př́ležitosti Rio + 20 (COPERNICUS Alliance, 2013). Staví na mnoha mezinárodních dohodách a závazcích, prohlášeních a národních iniciativách, které chtějí předefinovat principy vysokoškolského vzdělání, a zapojit širokou škálu zúčastněných stran z různých částí světa do dialogu o cílech tohoto procesu. Mezi jejím téměř 80 signatáři však téměř úplně chybí instituce ze zemí střední a východní 
Evropy $^{1}$, a tento nezájem Ize $v$ tomto regionu sledovat víceméně obecně: téma vzdělávání pro udržitelný rozvoj se zde reflektuje málo, a odborný dialog se vede jen sporadicky (srv. Barton, Dlouhá, 2014). To pravděpodobně souvisí s historickým vývojem vysokoškolského systému: od r. 1990 prochází ještě hlubší transformací, než vzdělávací systémy západních zemí, což klade velké nároky na zajištění prostého fungování vysokých škol (znalostní společnost prosazující se stále stoupajícím počtem studentů, důrazem na sledování kvality škol; vliv Boloňského procesu, který zajišt́uje prostupnost studia a tedy mobilitu studentů; a konečně kombinace těchto změn s přechodem od totalitních ideologických a nedemokratických praktik k plnému zajištění akademických svobod, viz též (Dlouhá, Moldan, 2013)). Přes dlouhou tradici environmentálně orientovaných oborů (ve většině zemí se odvíjí od požadavků vytčených již na Tbiliské konferenci v r. 1977) a nehledě na zvýšenou potřebu environmentálně vzdělaných odborníků v souvislostech se vstupem do Evropské unie (přijetí prísných environmentálních norem klade též personální nároky) se zde koncept VUR spíše neujal (Dlouhá, Moldan, 2012). Př́činou může být otevřená, transdisciplinární povaha tohoto typu vzdělávání, která klade nároky na rozvoj rozmanitých kompetencí spíše než pouhou technologicky založenou odbornost ${ }^{2}$.

\section{Kompetence ve VUR}

Kompetence učitelů ve VUR jsou důležitým faktorem hlubších změn ve výuce, a to i na vysokoškolské úrovni. Umožňují např́ílad efektivně pracovat v mezioborovém prostředí a př́padně též $\mathrm{s}$ dalšími neakademickými aktéry, vést studenty $\mathrm{k}$ aktivnímu podílu na společenské debatě a tvorbě souvisejících strategií, a všeobecně se zabývat budoucností a tím, jak k ní přistupovat. To vše jsou určující znaky VUR, které pomáhají nasměrovat výuku $k$ řešení otázek udržitelnosti. I zde totiž hrají důležitou roli principy VUR (Tilbury \& Mulà, 2009), viz Tabulka 1.

\footnotetext{
${ }^{1}$ resp. je zde pouze jediná, a to: „Envigogika, reviewed journal of the Charles University focused on ESD education, Czech Republic".

2 Obecně Ize říci, že vysokoškolské systémy vzdělávání v zemích střední a východní Evropy po dlouhém období nesvobody a ideologizace ještě v nedávné minulosti zaostávaly za západními zeměmi. $\checkmark$ posledních desetiletích pak prošly rychlou a intenzivní transformací (Kohoutek, 2009, s. 15-16), $v$ důsledku čehož dosud čelí četným společným problémům. Kromě toho se poslání akademických institucí změnilo: byly původně orientované pouze na výuku a nikoli na výzkum a inovace (Balazs et al., s. 616). V současné době jsou naopak výsledky výzkumu jedním z indikátorů kvality vysokých škol (ve střední a východní Evropě stejně jako na Západě) - je zde možno sledovat stoupající „poptávku” po odpovědnosti a dobře definovaném akademickém výkonu, což vede k upřednostňování disciplinární excelence před mezioborovými přístupy. Na druhé straně právě mezioborový přesah je jedním z podstatných rysů vzdělání pro udržitelný rozvoj (Salecedo-Rahola, Mulder, et al., 2012).
} 
Tabulka 1. Nejdůležitější principy VUR dle (Tilbury \& Mulà, 2009).

\begin{tabular}{|l|l|}
\hline $\begin{array}{l}\text { Myšlení pro budouc- } \\
\text { nost }\end{array}$ & $\begin{array}{l}\text { Myšlení pro budoucnost evokuje žádoucí vize budoucnosti. } \\
\text { Vede lidi k porozumění, co je udržitelný rozvoj; umožňuje také } \\
\text { reflektovat předpoklady takové interpretace. Tento proces } \\
\text { vede k tomu, že lidé cítí odpovědnost za tuto udržitelnou bu- } \\
\text { doucnost. }\end{array}$ \\
\hline $\begin{array}{l}\text { Kritické a kreativní } \\
\text { myšlení }\end{array}$ & $\begin{array}{l}\text { Kritické a kreativní myšlení umožňuje lidem objevovat nové } \\
\text { způsoby myšlení a jednání, přijímat informovaná rozhodnutí, } \\
\text { která jsou alternativou k současným zvyklostem. To zahrnuje } \\
\text { úvahy o vzájemných vztazích, kulturních souvislostech a no- } \\
\text { vých možnostech soužití. }\end{array}$ \\
\hline $\begin{array}{l}\text { Účast a participativ- } \\
\text { ní učení }\end{array}$ & $\begin{array}{l}\text { Angažovanost je předpokladem udržitelné budoucnosti. Důleži- } \\
\text { té je zapojení různých zainteresovaných aktérŭ a komunit, } \\
\text { protože je tak možno vést dialog mezi různými pohledy a př́- } \\
\text { stupy. Účast (a participativní učení) má také význam pro pocit } \\
\text { odpovědnosti a sounáležitosti. }\end{array}$ \\
\hline Partnerství & $\begin{array}{l}\text { Partnerství motivují ke změně. Podporují jednotlivce a organi- } \\
\text { zace, aby se podíleli na rozhodovacích procesech a vytvářeli } \\
\text { kapacity v oblasti udržitelného rozvoje. Mezikulturní partner- } \\
\text { ství jsou často zmiňována jako velmi důležitá pro vuR. }\end{array}$ \\
\hline Systémové myšlení & $\begin{array}{l}\text { Systémové myšlení má zásadní význam pro udržitelný rozvoj; } \\
\text { ukazuje se totiž, že dílčí přístupy nefungují, protože řeší jeden } \\
\text { problém, ale vytvářjí přitom další. Udržitelný rozvoj vyžaduje } \\
\text { př́stupy, které jou nad rámec řešení problémů a / nebo jejich } \\
\text { príčin a následků. }\end{array}$ \\
\hline
\end{tabular}

Diskuse o kompetencích vysokoškolských učitelů je vedena i v českém prostředí reflektuje celkové změny na tomto stupni vzdělávání a dlouhodobě se jí zabývají autoři především pedagogického zaměření (Vašutová, 2002, 2012; Štech, 1999; Bednaříková, 2012). Autoři shodně konstatují, že role vysokoškolského učitele se postupně proměňuje, je ovlivněna novými podmínkami a požadavky na vzdělání, ale také úlohou vysokých škol ve společnosti a jejich celkovou proměnou. Tyto změny souvisejí s prosazováním nové podoby procesu učení $v$ současné době (vycházející ze snahy překonat transmisivní pojetí výuky, zdůrazňující oboustranné aktivity učitele a studentů i jejich vzájemné interakce, podporující aktivní tvůrčí činnosti a také motivaci a zájem studentů, přičemž jsou nabízeny různorodé výukové metody a organizační formy); učitel pak má těmto kvalitativním změnám rozumět a napomáhat, srvn. (Bednaříková, 2012). Přesto jsou souvislosti těchto trendů $s$ potřebami a nároky VUR $v$ našem prostředí spíše podceněny (dokládají je jiné texty autorů.) 


\section{Kompetence dle návrhu EHK OSN}

$\mathrm{K}$ celkovým změnám ve vzdělávání směrem $\mathrm{k}$ udržitelnosti měla vést Dekáda vzdělávání pro udržitelný rozvoj OSN, která byla v regionu EHK OSN realizována prostřednictvím Strategie EHK OSN pro vzdělávání pro udržitelný rozvoj přijaté zástupci členských států ve Vilniusu $v$ roce 2005 (UNECE, 2005). Jedním z cílů této strategie bylo vybavit pedagogy kompetencemi pro výuku udržitelného rozvoje. Tento koncept byl dosud využíván zejména $v$ odborné prípravě učitelů - kompetence pro VUR se odrazily $v$ jejich počáteční $a$ průběžné odborné prípravě ve více než 80 \% zemí EHK OSN (Buckler \& Creech, 2014). Matice doporučených "kompetencí pro VUR", kterou vyvinula expertní skupina EHK OSN (UNECE, 2011)( viz též další texty autorů) v přípravné fázi sloužila také jako výchozí bod pro mapování a popis kompetencí pro VUR $v$ oblasti vysokoškolského vzdělávání $v$ rámci dále popsaného projektu i našeho šetření (UE4SD, 2014). Úplný seznam těchto sledovaných kompetencí přináší Tabulka 2. 
Tabulka 2. Kompetence učitelů pro VUR (UNECE, 2011) ${ }^{3}$

\begin{tabular}{|c|c|c|c|}
\hline & $\begin{array}{l}\text { HOLISTICKÝ P̌̌ÍSTUP } \\
\text { Integrativní myšlení a praxe }\end{array}$ & $\begin{array}{l}\text { PŘEDJÍMÁNÍ ZMĚNY } \\
\text { Minulost, prítomnost a budoucnost }\end{array}$ & $\begin{array}{l}\text { DOSAŽENÍ TRANSFORMACE } \\
\text { Lidé, pedagogika a vzdělávací systémy }\end{array}$ \\
\hline $\begin{array}{l}\text { Učit se znát } \\
\text { Učitel rozumí... }\end{array}$ & $\begin{array}{l}\text { - } \quad \text { základům systémového myšlení } \\
\text { - fungování sociálních, ekonomických a přírodních sys- } \\
\text { - } \quad \text { vémú a tomu, jak jsou propojeny } \\
\text { generačně, a mezislosti bztahů v současné generaci a mezi- } \\
\text { a přírodou } \\
\text { - svému světovému názoru a kulturním předpokladům, a } \\
\text { - snaží se porozumět názoru jiných } \\
\text { - vztahu mezi udržitelnou budoucností a naším myšlením } \\
\text { - a prístupem k životu a práci }\end{array}$ & $\begin{array}{l}\text { - } \quad \text { základním příčinám neudržitelného rozvoje } \\
\text { - že udržitelný rozvoj je vznikající koncept } \\
\text { - naléhavé potřebě změny od neudržitelných postu- } \\
\text { pů k podpoře zvyšování kvality života, rovnosti, so- } \\
\text { lidarity, a environmentální udržitelnosti } \\
\text { - důležitosti definovat problémy, kritické reflexe, } \\
\text { utváření vizí a kreativního myšlení v rámci plánová- } \\
\text { ní budoucnosti a působení na změnu } \\
\text { - významu připravenosti na nepředvídatelné situace } \\
\text { - a principu předběžné opatrnosti } \\
\text { - důležitosti vědecké evidence v podpoře UR }\end{array}$ & $\begin{array}{l}\text { - } \quad \text { proč je potřeba transformovat vzdělávací systémy, jež } \\
\text { - podporují učení } \\
\text { - proč je potřeba změnit způsob, jakým (se) učíme } \\
\text { - } \quad \text { dưležitosti toho, že je třeba stavět na zkušenosti učícího } \\
\text { - } \quad \text { je - to je základ změny a transformace } \\
\text { učení a pomení do reálných procesů přispívá k výsledkům } \\
\text { praxi }\end{array}$ \\
\hline $\begin{array}{l}\text { Učit se dělat } \\
\text { Učitel je scho- } \\
\text { pen... }\end{array}$ & $\begin{array}{l}\text { - vytvářet príležitosti pro sdílení informací a zkušeností z } \\
\text { rưzných oborů/míst/kultur/generací bez předsudků a } \\
\text { předběžných názorů } \\
\text { - } \quad \text { pracovat s různými perspektivami na dilematech, pro- } \\
\text { blémech, sporech a konfliktech } \\
\text { - rozumět (a učit porozumění) vlastní lokální a globální } \\
\text { sféře pưsobnosti }\end{array}$ & 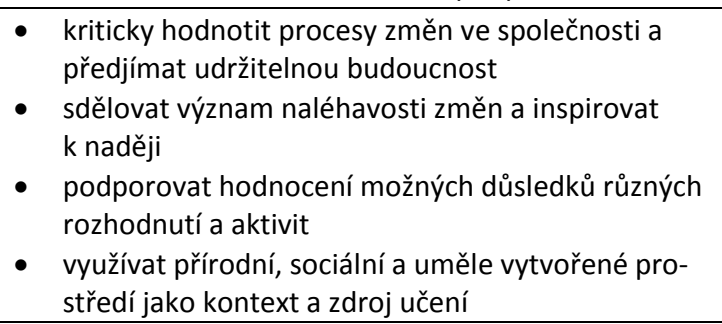 & 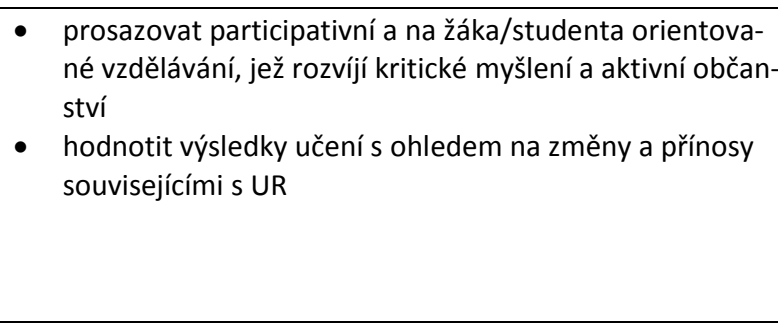 \\
\hline $\begin{array}{l}\text { Učit se být spo- } \\
\text { lu } \\
\text { Učitel pracuje } \\
\text { s ostatními tak, } \\
\text { že.... }\end{array}$ & $\begin{array}{l}\text { - aktivně (se) zapojuje do různých skupin napříc genera- } \\
\text { cemi, kulturami, místy a obory }\end{array}$ & $\begin{array}{l}\text { - } \quad \text { podporovat vznik nových světových názorů, které } \\
\text { - } \quad \text { nahrnují UR } \\
\text { - napomáhat jednání o udržitelné budoucnosti }\end{array}$ & $\begin{array}{l}\text { - } \quad \text { zpochybňuje neudržitelnou praxi napříč vzdělávacími } \\
\text { systémy včetně institucionální roviny } \\
\text { - } \quad \text { pomáhá žákům/studentům ujasnit si vlastní světový ná- } \\
\text { zor a názory jiných, a to prostřednictvím dialogu, a po- } \\
\text { chopit, že existuje alternativní rámec }\end{array}$ \\
\hline $\begin{array}{l}\text { Učit se být } \\
\text { Učitel je.... }\end{array}$ & $\begin{array}{l}\text { - Schopen zahrnout různé obory, kultury, perspektivy, } \\
\text { včetně domorodých či původních znalostí a názorů }\end{array}$ & 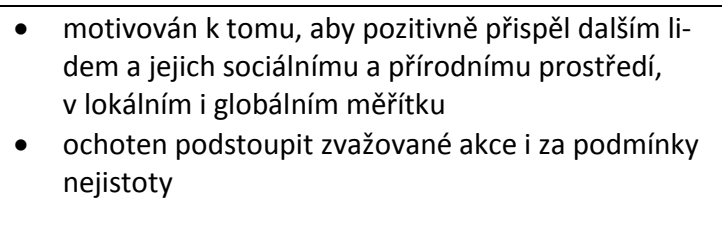 & $\begin{array}{l}\text { - } \text { ochoten zpochybňovat předpoklady neudržitelné praxe } \\
\text { - facilitátorem a účastníkem procesu učení } \\
\text { - } \quad \text { kriticky reflektujícím praktikem } \\
\text { - } \text { schopen inspirovat kreativitu a inovace } \\
\text { - zapojovat se do procesu učení tak, že vytváří pozitivní } \\
\text { vztahy s žáky/studenty }\end{array}$ \\
\hline
\end{tabular}

${ }^{3}$ Zdroj: UNECE (2011) Learning for the future: Competences in Education for Sustainable Development, ECE/CEP/AC.13/2011/6. Překlad Jana Dlouhá 


\section{O projektu UE4SD}

Mapování a analýze kompetencí vysokoškolských institucí pro VUR se věnoval projekt UE4SD, v jehož rámci se sešlo 53 partnerů z 33 států Evropy - ti poskytli strukturované informace o situaci ve svých zemích. Ty pak byly souhrnně zpracovány regionálními koordinátory pro každý z pokrytých regionů (Sever, Západ, Východ, Jih); tento článek přináší nejzajímavější výsledky pro region Východ a v některých aspektech je srovnává se situací v dalších zemích.

Projekt UE4SD je založen na spolupráci vysokoškolských institucí, jež jsou vůdčí v oblasti VUR ve své zemi co se týče podpory či programů rozvoje kompetencí VUR na této úrovni vzdělávání. Jeho nejnovějším výsledkem je publikace popisující dobrou praxi v pěstování kompetencí pro VUR na vysoké škole (UE4SD, 2015) - jde o výběr projektů nebo programů z prostředí vysokých škol, které ukazují zajímavé přístupy nebo inovace $v$ profesním rozvoji univerzitních pedagogů. Jedním z prínosů této publikace je popis netradičních metod a postupů výuky na vysokých školách, a to na zde uvedených 13 príkladech dobré praxe. Vznikl tak soubor modelových příkladů, které je možno využít v různých kulturních kontextech a vysokoškolských prostředích; publikace přináší též shrnutí předpokladů a politik VUR na evropské úrovni, soubor doporučení pro policy-makery, a řadu dalších návodů využitelných v praxi.

Výběru nejlepších př́ikladů předcházela fáze mapování situace ve všech zúčastněných zemích - v jejím rámci byly zjištóvány předpoklady pro výuku UR a specificky VUR na vysokých školách, a to z hlediska vzdělávacích politik, vysokoškolské praxe i existence "zapálených" učitelů, kteř́ jsou v mnoha př́padech hybnou silou takto orientované výuky. Z každé země, která se projektu účastnila, byly též popsány 3 př́iklady ilustrující toto téma - celkem tak bylo získáno přibližně 100 prríkladů, jejich obsah byl poměrně různorodý a bylo potřeba se $v$ něm vyznat. Toto mapování pak bylo ve všech 4 regionech vyhodnoceno (výsledkem jsou regionální zprávy), a souhrnně zpracováno pro všechny zúčastněné země (souhrnná zpráva, UE4SD, 2014).

\section{Cíl spolupráce - explorativní výzkum}

Všechny tyto kroky vedly ke zkoumání velmi úzce zaměřeného problému: jak se uskutečňuje profesní rozvoj vysokoškolských učitelů, a to z hlediska zvláštních kompetencí pro udržitelný rozvoj a s ohledem na kvalitu vysokoškolské výuky jako takové. Cílem bylo určit předpoklady těchto změn ve vysokoškolské praxi, i to, jak $v$ jednotlivých zemích a institucích probíhají a $\mathrm{k}$ čemu to vede - jak jsou tyto možnosti využívány a co nově nabyté kompetence učitelů do výuky přináśí. Zjistilo se tak, jak jsou principy VUR chápány v různých kulturních kontextech a překládány do skutečných aktivit - pedagogických metod a postupů. Ty jsou na vysokoškolské úrovni často podceňovány a ještě méně reflektovány (Tilbury, 2011) - pro tento široce pojatý výzkum však omezený počet existujících programů byl výhodou: jelikož pracoval s 53 institucemi po celé Evropě, zjednodušila se tím značně jeho nepřehlednost.

\section{Metoda}

Tento článek se zabývá uplatněním kompetencí pro udržitelný rozvoj ve vysokoškolské výuce $v$ oblasti střední a východní Evropy a srovnáním tohoto fenoménu s dalším evropskými regiony. $\mathrm{K}$ tomu využívá výsledků projektu UE4SD (které byly dosaženy autory tohoto článku) a dalších navazujících analýz. Hlavní výzkumné téma - popis (podmínek pro) rozvoj kompetencí vysokoškolských učitelů ve VUR - má osvětlit situaci ve vysoko- 
školské výuce a podmínky pro její transformaci $k$ udržitelnosti. $K$ tomu jsou $v$ diskusní části doplněny některé informace $z$ širšího kontextu vzdělávací politiky zkoumaných zemí.

\section{Oblast výzkumu}

Projektu se účastnilo 12 zemí z regionu Východ a jejich informace byly zahrnuty do tohoto výzkumu: Albánie; Bosna a Herzegovina; Bulharsko; Chorvatsko; Česká republika; Mad’arsko; Makedonie; Polsko; Rumunsko; Srbsko; Slovensko; Slovinsko. Zvýrazněné země byly zastoupeny dvěma vysokoškolskými institucemi; ty spolupracovaly na př́pravě své národní zprávy, takže dodaly konzistentní soubor odpovědí a tři prípadové studie, podobně jako ostatní země, kde zpracovatelem byla jen jedna instituce (počet př́padových studií se ovšem lišil; za Českou republiku byly zpracovány studie 4, kdežto některé další země dodaly pouze 2 př́padové studie, nebot' nenalezly jiné vhodné príklady). Analýza těchto národních zpráv se zaměřuje hlavně na specifika regionu střední a východní Evropy, aniž by ovšem bylo provedeno širší srovnání s dalšími třemi regiony zastoupenými $v$ projektu ( $v$ tomto ohledu jsou získaná data většinou irelevantní).

Situace $v$ zemích $z$ těchto dalších regionů je zmíněna pouze stručně a srovnání výsledků $z$ těchto oblastí se zkoumaným regionem je provedeno pouze $v$ jednom prípadě.

\section{Postup}

Projekt byl založen na úzké spolupráci s vysokoškolskými učiteli z partnerských institucí v evropských zemích, a to především v rámci 4 regionů - Východ, Západ, Sever, Jih ale i napríč těmito regiony. Uskupení bylo vedeno tzv. Steering Group, která se skládala z regionálních koordinátorů; ti pak shromažd'ovali informace ze svých spádových oblastí. Výzkumu předcházela př́íravná fáze, $v$ jejímž rámci byl vybrán koncept kompetencí vhodný pro vysokoškolské učitele dle (UNECE, 2011) - viz Tabulka 2, naplánován způsob, jak s ním pracovat (prosté zvážení, zda vyjmenované kompetence jsou uplatňovány ve výuce), a navržena struktura dotazníku pro rozeslání každému z 53 partnerů, i jeho jednotlivé otázky. Ty se týkaly předpokladů pro rozvoj sledovaných kompetencí v dané zemi a instituci; uplatnění některých důležitých přístupů; a existence programů, kde jsou dané kompetence náplní či prostředkem výuky - tyto programy včetně jejich dopadu byly popsány formou strukturovaných př́padových studií. $V$ závěru každé př́padové studie byla přiložena tabulka kompetencí dle UNECE, z nichž respondenti vybrali kompetence relevantní pro daný prípad.

Dotazníky pak byly všemi partnery vráceny a následně je koordinátoři vyhodnotili vznikly tak regionální zprávy o situaci. Zprávy ze všech 4 regionů byly vytvořeny $\checkmark$ jednotném formátu těsně sledující strukturu dotazníku distribuovaného každému z partnerů; v úvodní části shrnuje jednotlivé odpovědi, a dále nabízí všechny shromážděné př́padové studie $v$ jednotlivých zemích. Díky tomuto standardizovanému postupu pak na základě tohoto mapování ve všech 4 regionech byla vytvořena souhrnná zpráva (UE4SD, 2014), která vybrala nejdůležitější obecné poznatky a do určité míry je analyzovala (analýzu nelze pokládat za úplnou, neprošla totiž všemi potřebnými fázemi: např́klad sběr dat se mohl $v$ jednotlivých regionech lišit - přestože byl pro něj vytvořen jednotný postup, jeho interpretace mohla být $v$ různých kulturních kontextech různá). Autoři tohoto článku prošli celou tuto cestu za region Východ, a přináší tak zde její nejdůležitější závěry pro českého čtenáře. Jestliže cílem celého projektu UE4SD bylo popsat všeobecnou situaci a zjistit zde podmínky pro VUR na VŠ úrovni, regionální zpráva za Východní oblast chtěla mj. nalézt určitá specifika vycházející ze společného dědictví minulosti, a srovnat tyto zvláštnosti s ostatními regiony - tato studie má podobné cíle specificky se týkající kompetencí vysokoškolských učitelů. 
Srovnání mezi všemi regiony zde bylo provedeno pouze u otázky Jaké př́stupy a principy ve VUR jsou podporovány národními strategiemi VUR? - ta má velmi pravděpodobně přímou souvislost s rozvojem kompetencí. Jednotlivé kategorie prístupü a principů v ní obsažených vznikly přepracováním Tabulky 1 (dle Tilbury \& Mula, 2009) skupinou autorů Souhrnné zprávy (UE4SD, 2014) - viz Tabulka 3.

Tabulka 3. Př́istupy a principy VUR pro hodnocení vysokoškolské výuky z hlediska kompetencí (UE4SD, 2014).

\begin{tabular}{|l|l|}
\hline Přistupy ve VUR & celoinstitucionální přistup \\
\cline { 2 - 2 } & strategické/systémové myšlení \\
\cline { 2 - 2 } & kompetence/dovednosti \\
\cline { 2 - 2 } & myšlení budoucnosti \\
\hline Principy VUR & kritické/kreativní myšlení \\
\cline { 2 - 2 } & akční výuka/učení \\
\cline { 2 - 2 } & systémové myšlení \\
\cline { 2 - 2 } & participace/partnerství \\
\hline
\end{tabular}

\section{Šetření}

Nástrojem výzkumu byl dotazník obsahující sérii otázek a strukturu případové studie, jehož plnou verzi Ize nalézt $v$ každé $z$ regionálních zpráv. Otázky se týkaly obecných předpokladů pro VUR na vysokoškolské úrovni, profesního rozvoje vysokoškolských pedagogů; součástí tohoto zadání bylo popsat 3 prípadové studie $z$ každé země, které se zvláště zaměřly na kompetence vznikající při popisované výuce. $V$ tomto textu se však nezabýváme všemi okruhy položených otázek (resp. odpovědi na ně nejsou relevantní pro téma tohoto článku), a předkládáme pouze analýzu shromážděných tabulek kompetencí z jednotlivých prípadových studií. Znění dalších otázek uvádíme pouze u některých souvisejících problémů a témat, která jsou důležitá pro pochopení širších souvislostí.

Tabulka byla respondenty vyplněna tak, že byl proveden výběr relevantních kompetencí z kompletního seznamu (viz Tabulka 1 - kompetence dle UNECE). Někteří respondenti místo takto nabídnutých kompetencí předložili vlastní popis (ten pak bylo možné převést na jednotný „modelový" popis kompetencí UNECE, pokud by účelem bylo kvalitativní srovnání jednotlivých př́padových studií); výhodou bylo hlubší zamyšlení respondentů a zachycení širšího spektra kompetencí. $V$ této studii nás však bude zajímat pouze počet takto popsaných kompetencí v jednotlivých kategoriích VUR (holistický př̌stup, předjímání změny, dosažení transformace), a v př́slušných doménách učení pro každou z těchto kategorií (učit se poznávat, učit se jednat, učit se žít společně, učit se být). Pro analýzu byl použit počet kompetencí $v$ těchto kategoriích a doménách učení, jak je respondenti uvedli v každé z prípadových studií; protože ne všechny země zpracovaly 3 prípadové studie ( $v$ některých případech nebylo možné nalézt 3 relevantní príklady $v$ dané zemi a byly předloženy pouze 2 ), bereme zde $v$ úvahu průměr počtu všech zmíněných kompetencí na jednu prípadovou studii $v$ dané zemi. 
Z toho, kolik kompetencí je $v$ každé kategorii/doméně uvedeno, můžeme usuzovat na relativní důležitost dané kategorie/domény kompetencí pro vzdělání pro udržitelný rozvoj ve sledovaných případech, což by mohlo mít implikace pro popis situace $v$ jednotlivých zemích i celém regionu. Počet kompetencí v dané kategorii/doméně samozřejmě nesouvisí s jejím významem kauzálně: ilustruje pouze způsob, jakým o ní respondenti referovali, zda a jak ji brali v úvahu. Celkový význam rozvoje kompetencí v profesním vzdělávání vysokoškolských pedagogů se tak dále pokoušíme osvětlit v širším kontextu - interpretací výsledků analýzy některých dalších otázek dotazníku, které se explicitně týkají kompetencí a ilustrují například národní legislativu, VUR ve strategických dokumentech vysokých škol, nebo počet iniciativ na podporu kompetencí VUR v jednotlivých zemích na VŠ úrovni (zde jde o prostý souhrn odpovědí). Souhrnně za všechny regiony jsou pak reflektovány metody či příležitosti k rozvíjení těchto kompetencí na úrovni vysokých škol.

\section{Výsledky}

Jak uvedeno výše, v následující analýze jsme brali v úvahu vždy průměr počtu všech zmíněných kompetencí $v$ dané kategorii/doméně na jednu př́padovou studii $v$ dané zemi. První dva výsledky vycházejí ze souhrnu počtu kompetencí za všechny 4 domény spadající do dané kategorie $v$ dané zemi; ve druhých dvou případech jsme brali v úvahu souhrn počtu kompetencí za všechny 3 kategorie spadající do dané domény.

\section{Graf 1. Počet kompetencí v jednotlivých kategoriích ve všech zkoumaných zemích regionu Východ. Barvy sloupců se liší dle kategorií: viz legenda k obrázku.}

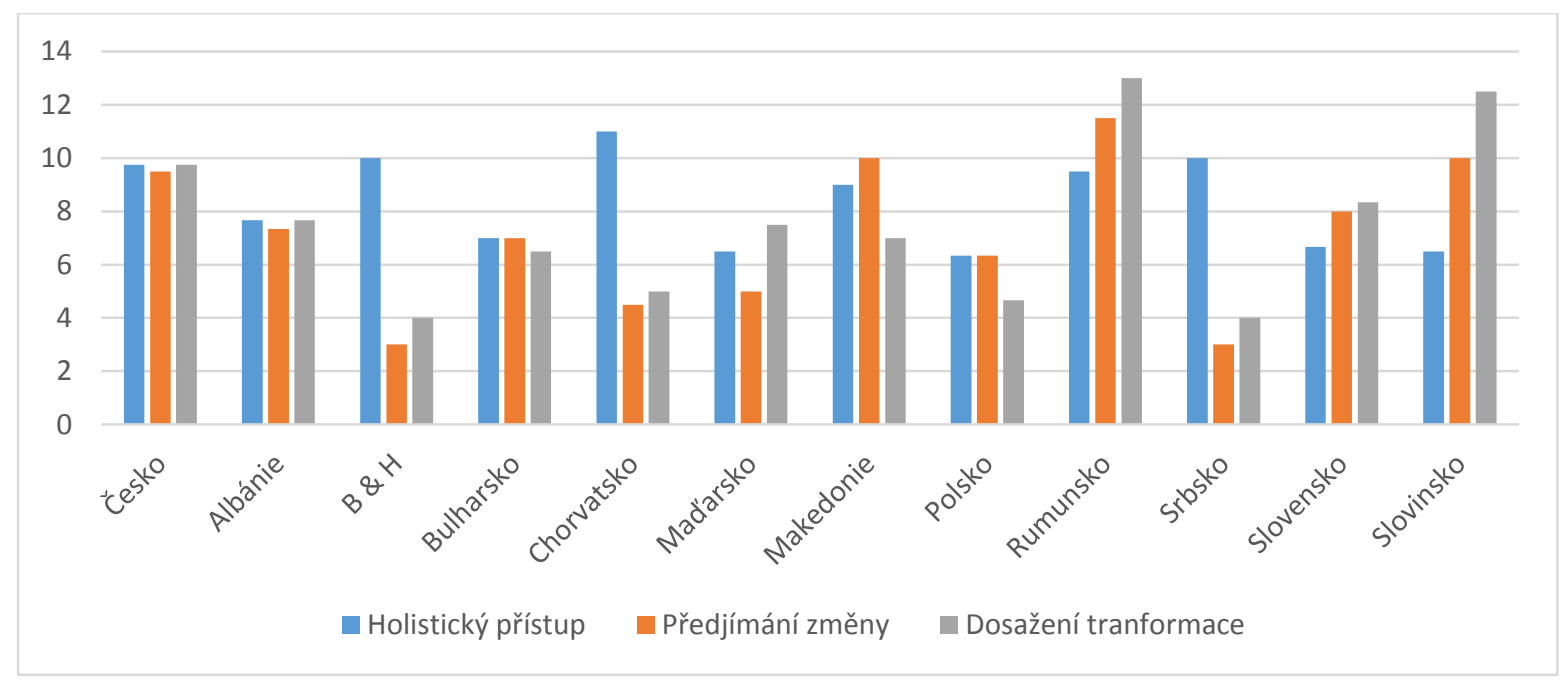


Graf 2. Celkový počet kompetencí v jednotlivých kategoriích za všechny sledované země - region Východ.

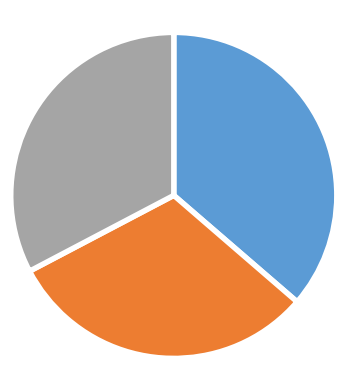

- Holistický př́stup - Předjímání změny — Dosažení tranformace

Graf 3. Počet kompetencí v doménách učení v jednotlivých doménách učení ve všech zkoumaných zemích regionu Východ. Barvy sloupců se liší dle domén: viz legenda k obrázku.

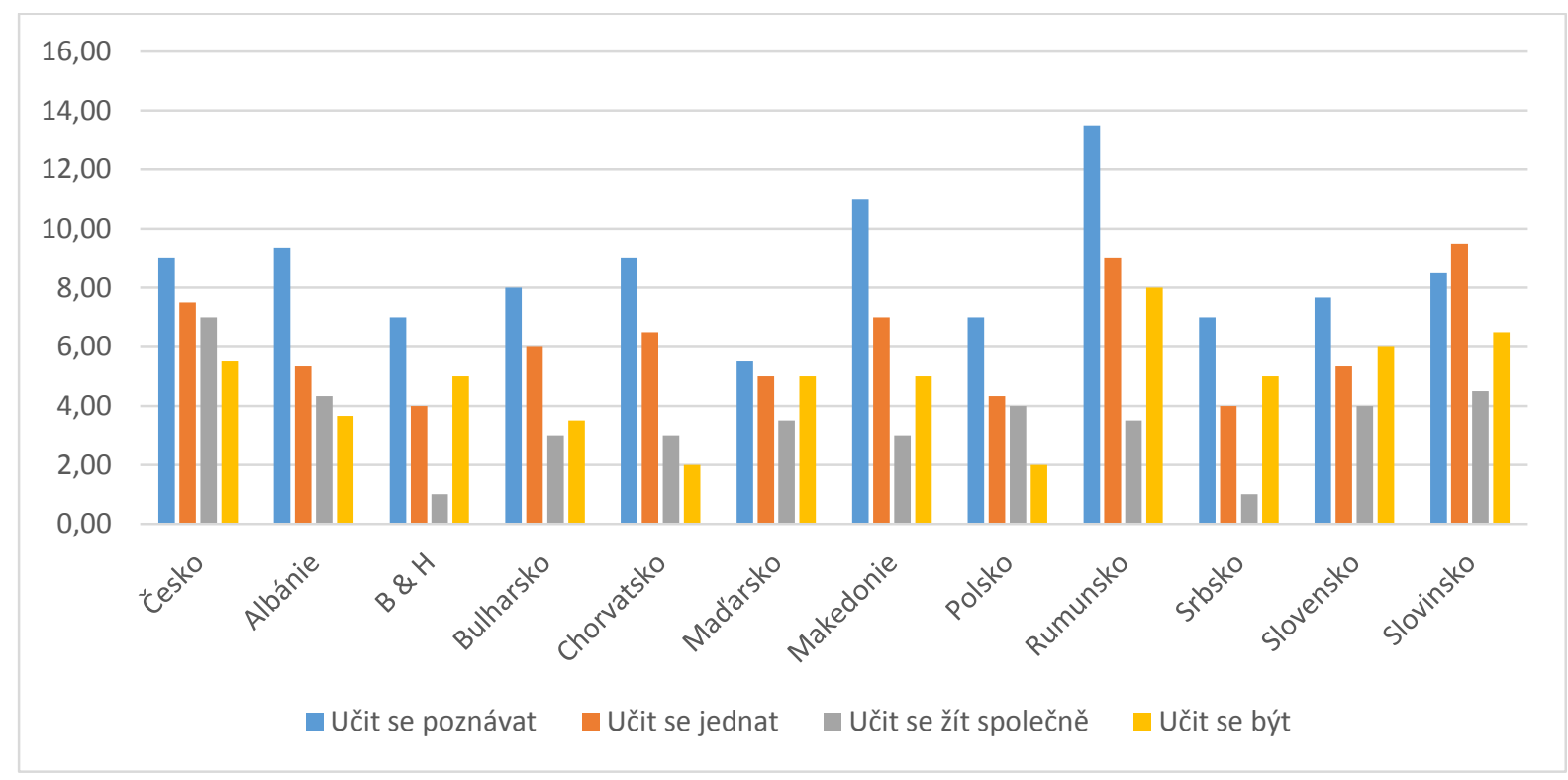

Graf 4. Celkový počet kompetencí v doménách učení za všechny sledované země - region Východ.

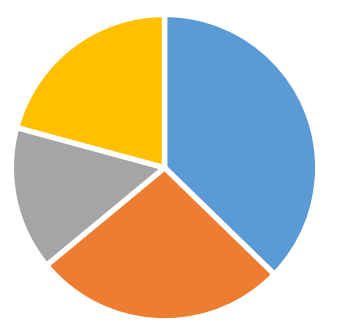

\footnotetext{
- Učit se poznávat = Učit se jednat

- Učit se žít společně - Učit se být
} 


\section{Výsledky analýzy dalších otázek dotazníku}

Pro interpretaci zjištěného počtu kompetencí a pochopení širšího kontextu vzdělávacích politik jednotlivých zemí a podmínek pro jejich rozvoj na vysokoškolské úrovni zde dále uvádíme analýzu vybraných výsledků, jež byly získané při zpracování regionální zprávy pro region Východ. Tyto údaje byly jinou formou zpracovány do Souhrnné zprávy (UE4SD, 2014), kde jsou srovnány s dalšími regiony (je tedy možno zde zjistit regionální rozdíly).

Na otázku, zda v národní legislativě či dokumentech je zmíněno profesní vzdělávání ve VUR vysokoškolských pedagogư (vyžadující například určité schopnosti či dovednosti), spolupracující partneři z 9 zemí uvedli, že není, a pouze 3, že ano (levý sloupec v Tabulce 4). Mezi odpověd'mi na otázku, zda a kolik mají vysokoškolské instituce strategických plánů nebo směrnic podporujících VUR, bylo podobně málo pozitivních - univerzity dokládaly, že takové plány nemají bud' žádné, nebo jich mají velmi málo (prostřední sloupec v Tabulce 4). Jedna z otázek se také týkala toho, zda vysokoškolské instituce mají vlastní programy nebo jiné iniciativy v oblasti profesního rozvoje vysokoškolských učitelů, které by zohledňovaly modelový návrh kompetencí ve VUR (UNECE, 2011) (pravý sloupec v Tabulce 4).

\section{Tabulka 4. Přehled odpovědí na otázky o (přijetí strategií) VUR na úrovni vyso- kých škol.}

Levý sloupec: zmínky o profesním vzdělávání vysokoškolských pedagogů ve VUR v národní legislativě či dokumentech - region Východ (dvoustupňová škála odpovědí Ano-Ne).

Prostřední sloupec: přehled o množství strategických plánů nebo směrnic podporujících VUR, které přijaly vysokoškolské instituce $v$ jednotlivých zemích - region Východ (pětistupňová škála odpovědí: Žádné; Málo; Několik; Hodně; Všechny).

Pravý sloupec: přehled o vlastních programech vysokých škol nebo jejich jiných iniciativách $v$ oblasti profesního rozvoje vysokoškolských učitelů zohledňujícího kompetence pro VUR - region Východ (dvoustupňová škála odpovědí Ano-Ne).

\begin{tabular}{|l|c|c|c|}
\hline & $\begin{array}{c}\text { Zmínky O VUR } \\
\text { v legislativě \& } \\
\text { dokumentech }\end{array}$ & $\begin{array}{c}\text { Množství plánů \& } \\
\text { směrnic VŠ }\end{array}$ & $\begin{array}{c}\text { Existence iniciativ } \\
\text { \& programů vš }\end{array}$ \\
\hline Albánie & Ne & Málo & Ano \\
\hline Bosna a Herzegovina & Ne & Žádné & Ne \\
\hline Bulharsko & Ne & Málo & Ano \\
\hline Chorvatsko & Ne & Žádné & Ne \\
\hline Česko & Ne & Žádné & Ano \\
\hline Mad'arsko & Ne & Několik & Ano \\
\hline Makedonie & Ne & Žádné & Ne \\
\hline Polsko & Ne & Málo & Ne \\
\hline Rumunsko & Ne & Žádné & Ne \\
\hline Srbsko & Ano & Žádné & Ne \\
\hline Slovensko & Ano & Žádné & Ne \\
\hline Slovinsko & Ano & Málo & \\
\hline
\end{tabular}




\section{Srovnání s dalšími evropskými regiony - Západ, Sever, Jih}

Pro celkové srovnání situace napříč regiony byly vybrány odpovědi na otázku: Které přístupy a principy ve VUR jsou podporovány národními strategiemi VUR? Ty totiž dobře ilustrují diverzitu pedagogických metod, které Ize na vysokoškolské úrovni využít pro rozvoj kompetencí ve VUR. Důraz na rozmanitost pedagogických přístupů a principů je podmínkou pedagogicky založené reflexe a plánování výuky, a to z kriticky a konstruktivisticky založeného úhlu pohledu, který je jedním z východisek vzdělání pro udržitelný rozvoj.

\section{Graf 5. Přehled nejdůležitějších přístupů a principů VUR ve všech sledovaných zemích Evropy.}

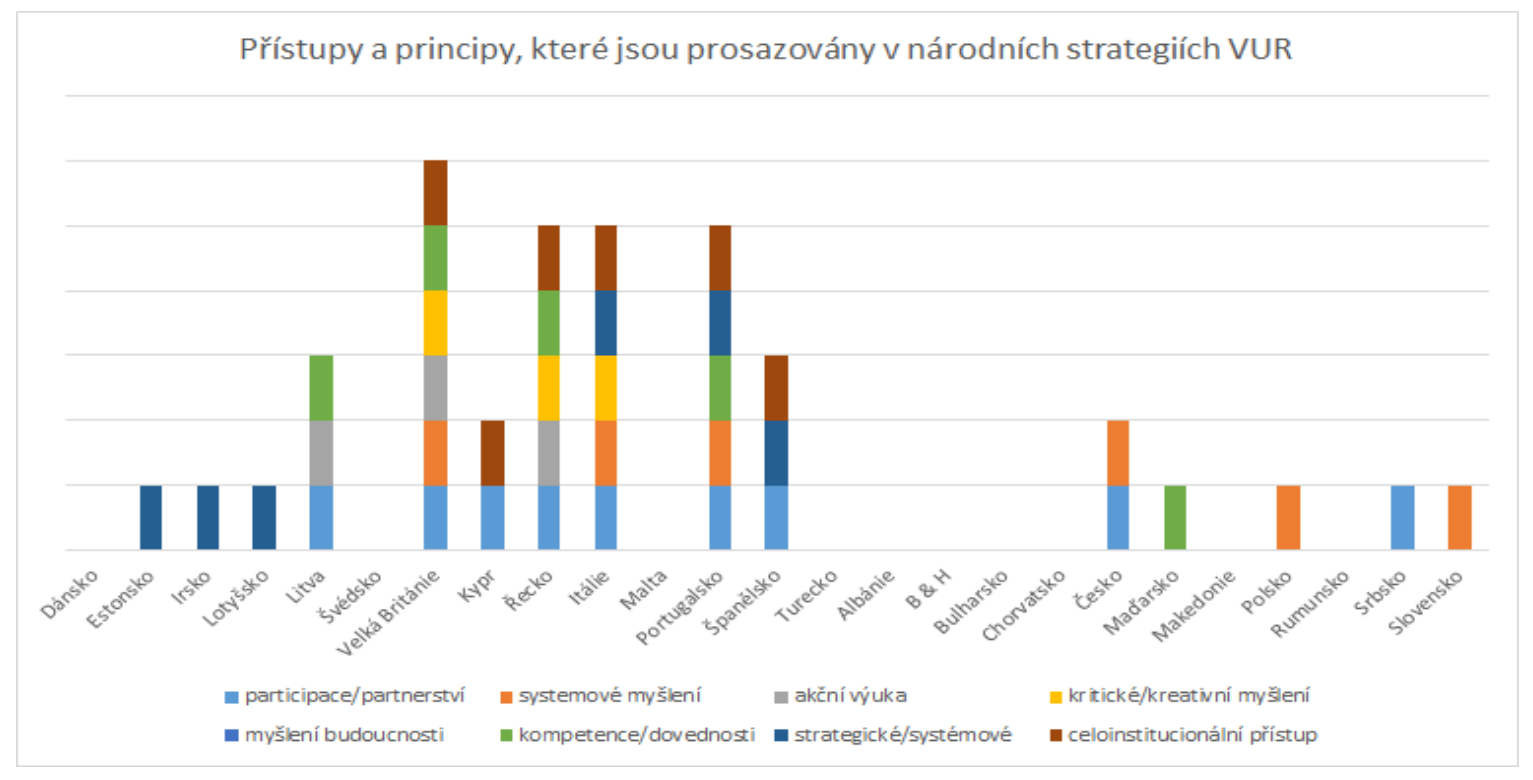

\section{Diskuse}

Metoda dotazníkového šetření, kde respondenty byli „informovaní experti" v každé ze sledovaných zemí, byla v této studii kombinována s jejich vlastní analýzou národní situace, kterou prováděli na základě studia dokumentů, interview s klíčovými aktéry a podobně (viz Regionální zprávy, kapitola Shromažd’ování a validace dat pro národní zprávy v každé z nich). Takto získané údaje Ize považovat za výsledky výzkumu s omezenou vypovídací hodnotou, a to z důvodu poměrně různého přístupu respondentů ke zpracování otázek a nepřiliš četné vzájemné komunikace - ta probíhala převážně přes regionální koordinátory. Jde tedy spíše o informovaný popis situace, jehož dalším zpracováním vzniká mapa přiležitostí a nedostatků v profesním vzdělávání vysokoškolských pedagogů ve VUR. Jako taková má sloužit praktickým cílưm projektu: výběru ukázkové dobré praxe a následné snaze pomocí takto získaných modelových příkladů a nástrojů zaplnit "bílá místa" ve VUR na méně rozvinutých institucích a oblastech. $V$ našem případě pak má pomoci předběžně určit rozdíly sledovaného regionu Východ od zbytku Evropy a zjistit faktory, které jsou pro transformaci vysokoškolské výuky směrem k udržitelnosti nejdůležitější. Výsledky zde předložené jsou tedy povahy explorativní; je třeba je pokládat za předběžné, na jejichž základě Ize teprve položit specifické výzkumné otázky. 
Ze srovnání kompetencí popsaných $v$ prípadových studiích vyplývají následující poznatky; úplnou analýzu kompetencí $v$ jednotlivých doménách a kategoriích napříc všemi regiony Ize nalézt v Souhrnné zprávě (UE4SD, 2014, str. 49-53):

Celkově jsou kompetence $v$ jednotlivých kategoriích (holistický př́stup, předjímání změny, dosažení transformace) ve zkoumaných zemích regionu rozloženy poměrně vyrovnaně (graf 2). Rozložení těchto kategorií se ovšem liší v jednotlivých zemích (graf 1); překvapivý je důraz možnosti a uskutečnění změn v některých zemích. Vysvětlení by mohlo spočívat v podrobnějším popisu (a případné kategorizaci) samotných prípadových studií: je např́klad patrné, že kompetence změny a dosažení transformace, byly ve větší míře dosaženy $\vee$ príkladech spíše prakticky orientovaných projektů, které však nebyly přiliš relevantní pro rozvoj pedagogických kompetencí (Albánie, Mad'arsko, Slovinsko) nebo se jednalo o iniciativy založené na dobré znalosti teorií VUR, nicméně s malým dopadem do všeobecně přijaté vysokoškolské praxe (Česká republika, Slovensko - tam šlo spíše o první kroky $v$ jednání s policy-makery). Tam, kde byl zdůrazňován holistický přístup, šlo většinou o čistě environmentální př́istupy (směřující například k ochraně př́rody a zdrojů).

Co se týče domén učení, nejvíce kompetencí bylo popsáno v doméně učit se poznávat; nicméně i další domény (učit se jednat; učit se žít společně; učit se být) jsou zastoupeny téměř ve všech sledovaných př́ikladech (graf 4), ačkoli jejich rozložení je ve zkoumaných zemích značně nevyrovnané (graf 3 ). Zde Ize z rozdílného počtu kompetencí $\checkmark$ jednotlivých doménách vyvozovat jen omezené závěry, protože tyto kompetence jsou už ve vzorové tabulce (viz Tabulka 2) zastoupeny nerovnoměrně; respondenti regionu Východ však většinou hledali vlastní popis kompetencí v jednotlivých doménách ${ }^{4}$. Můžeme si tak pouze klást otázku, zda důraz na znalostní doménu může souviset $s$ tradiční orientací vysokoškolské výuky $v$ tomto regionu na environmentální problémy a jejich řešení. Tuto domněnku však nepodporuje srovnání grafu $1 \mathrm{~s}$ grafem 3 - do kategorie holistický př́stup (důležitá v environmentálním myšlení) nespadají stejné země a jejich př́klady, jako ty, které kladou důraz na znalostní doménu. Je poměrně překvapivé, že doména učit se být se celkově vyskytuje ve větším počtu případů, než doména učit se žít společně.

Z porovnání odpovědí na další otázky zodpovězené respondenty ve zkoumaných zemích Ize usuzovat, že $v$ regionu střední a východní Evropy je poměrně málo příležitostí $k$ profesnímu rozvoji vysokoškolských učitelů obecně, a pěstování kompetencí VUR $v$ jeho rámci zvláště (viz tabulka 4). Profesní rozvoj není zpravidla zmíněn $v$ národní legislativě či dokumentech (třebaže se $v$ těchto dokumentech zmínky o VUR občas vyskytují, což vyplývá z odpovědi na jinou, zde nezmíněnou otázku, viz Zpráva regionu Východ); vzdělávání pro udržitelný rozvoj a/nebo kompetence UNECE nejsou zase podporovány samotnými vysokými školami (nejsou obsahem jejich strategií, směrnic, a nejsou ani součástí jejich iniciativ nebo aktivit). Podmínky pro rozvíjení těchto kompetencí tak ve sledované zeměpisné oblasti nejsou př́liš příznivé. Celkově Ize říci, že užívané přístupy a principy VUR jsou ve srovnání s dalšími regiony $v$ dokumentech týkajících se vysokoškolské výuky zohledněny velmi málo (graf 5 ). Je otázkou, které $z$ těchto jevů jsou příčinou a které důsledkem (tedy zda legislativa a dokumenty podmiňují iniciativy vysokých škol, jsou vzájemně nezávislé, nebo platí obrácená kauzalita).

Takto získané výsledky je třeba chápat $v$ širších souvislostech Regionální zprávy. Vyplývá z ní např́klad, že jedna z velmi aktivních univerzit celé oblasti usilující o titul „udr-

\footnotetext{
${ }^{4} \mathrm{Na}$ rozdíl od dalších regionů, kde pouze vybírali ze seznamu kompetencí UNECE, byli partneři ze zemí střední a východní Evropy vyzváni, aby cílové kompetence formulovali sami; většinou tak učinili, avšak vzorová tabulka UNECE kompetencí jim byla často inspirací.
} 
žitelná univerzita" (slovinská Univerzita Maribor) se zaměřuje spiše na praktické a výzkumně orientované aktivity než na cíle samotného vzdělávání pro udržitelný rozvoj, jak se projevují ve vysokoškolské pedagogice (Lukman et al., 2009). Změny v prístupech a principech výuky/učení jsou tak bud' zanedbanou či nereflektovanou součástí celkových změn vysokoškolského kurikula směrem $\mathrm{k}$ udržitelnosti. Regionální zpráva o kompetencích vysokoškolských učitelů ve VUR přináší dále následující zkušenosti a závěry:

- Jak vyplývá též z širšího kontextu, v tomto regionu dosud neexistuje př́liš velký prostor pro uplatnění a reflexi rozmanitosti pedagogických přístupů ve vysokoškolském vzdělávání. Úzké oborové zaměření a snaha o dosažení efektivních řešení environmentálních problémů totiž poskytují okamžité vědecké výsledky, což má obecně větší šanci zlepšit mezinárodní postavení akademických institucí (srovnávací řebříčky). Univerzity se $v$ současnosti velmi snaží obnovit svou mezinárodní prestiž; v daném prípadě se to projevuje větším zájmem o rozvoj technologicky zaměřených environmentálních oborů.

- $\quad V$ této geografické oblasti se tradičně projevuje silná role vůdčích osobností: v mnoha zemích závisí prosazení VUR na úsilí angažovaných jednotlivců. Někdy dokonce jejich iniciativy do jisté míry nahrazují absenci národního systému pro profesní rozvoj vysokoškolských pedagogů.

- Systémová opatření jsou i na vysokoškolské úrovni brzděna častými politickými změnami a turbulencemi. Politické priority $v$ tomto regionu nejsou stabilní, a někdy je tak obtížné zajistit dlouhodobější platnost rozhodnutí a strategií. Vysoké školy mohou být $v$ tomto ohledu stabilizujícím faktorem, napríklad si mohou podržet interní politiku VUR (existuje-li) např́č režimy.

- Je zde nedostatek podpory pro koncepci samotného udržitelného rozvoje, a $v$ důsledku toho není též vzdělávání pro udržitelný rozvoj (VUR) často vnímáno jako priorita. Někdy začíná být pojem udržitelný nahrazován jinými obecnými pojmy a principy, napríklad globálním vzděláváním (to se děje např. na Slovensku).

- I když to nebylo výslovně analyzováno, v tomto regionu se často nerozvíjí „myšlení orientované na budoucnost" (umění vytvářet vize budoucnosti a relevantní celospolečenské strategie; také uvádění takových představ do praxe představuje problém). Iniciativy a činnosti jsou stále řízeny spiše restriktivně - předpisy, normami a kontrolními mechanismy.

- Ucelené systémy pro profesní rozvoj vysokoškolských pedagogů, do jejichž rámce by kompetence pro VUR mohly být začleněny, všeobecně chybí (např. v Chorvatsku; zdůrazňují to také zprávy ze Slovenska, Slovinska a České republiky). Na druhé straně Ize dobrý př́klad rozvoje kompetencí VUR v programech na vysokoškolské úrovni nalézt napríklad $v$ Rumunsku, kde existuje systém povinného sociálně-psychologicko-pedagogického vzdělávání pro studenty učitelství (nástavbové a vysokoškolské studium).

- Holistické, mezioborově založené a transformativní vzdělávání se často považuje za důležitý předpoklad VUR, ale systémově tyto principy obvykle přijaty nejsou. Např́klad v Bosně a Hercegovině se uvádí, že jsou často $v$ rozporu s dominantním vzděláváním a postoji a modely rozvíjenými všeobecně ve výuce; tato nekompatibilita mezi stávajícími programy na straně jedné a koncepcemi VUR na straně druhé je pak zásadní překážkou změny př́stupu. 
- Pro to, aby kompetencím vysokoškolských pedagogů byla věnována větší pozornost, je zapotřebí změn ve vzdělávací politice. Slovinsko volá po strategickém dokumentu, který by pro vzdělávání pro udržitelný rozvoj na vysokoškolské úrovni poskytl formální rámec, $v$ němž by pak mohlo být zahrnuto více různých oborů a jejich kombinací. Tento dokument by měl být $v$ souladu $s$ mezinárodními dokumenty předloženými OSN (UNESCO, EHK OSN) či EU, a měl by mít vliv na další národní dokumenty.

- Mají-li pro podporu VUR existovat podložené argumenty a důkazy, je velmi zapotřebí provádět reflexi a/nebo výzkum. V Albánii např́íklad nedostatek argumentů $z$ výzkumu vedl k nepochopení VUR a jeho role ve společnosti. Výzkum týkající se pedagogiky VUR a možných inovací v tomto rámci je tedy jednou z hlavních priorit; vysokoškolské vzdělávání by mělo v tomto ohledu hrát významnou roli (viz EHK OSN, 2005).

Je dále patrné, že oborová orientace je v zemích střední a východní Evropy hluboce zakořeněnou součástí akademické kultury, zatímco $v$ oblasti udržitelného rozvoje je vyžadován mezioborový přístup a širší zapojení aktérů neboli zúčastněných stran (SalecedoRahola, Mulder, et al., 2012) Zavedení principů udržitelnosti do vysokoškolského systému a uplatnění souvisejících aktivit (včetně rozvoje kompetencí) tak zde čelí poměrně značným potížím, protože univerzity nemohou jednoduše ponechat stranou své tradiční cíle a překonat zavedené přístupy. Stále ještě „zisky" z takových změn zdaleka nevyvažují potíže s nimi spojené.

\section{Závěr}

Přestože vysoké školy v zemích střední a východní Evropy prošly od roku 1990 obdobím hluboké transformace a jejich uspořádání, zásady fungování a nakonec i úroveň se přiblížily podobným institucím vyspělých zemí, tyto změny nejsou nutně následovány proměnou institucí směrem $k$ udržitelnosti, jak ji známe $z$ některých př́kladů odjinud. Ze zpráv o situaci $v$ regionu Východ vypracovaných informovanými experty jednotlivých zemí a $z$ analýzy provedené $v$ tomto textu vyplývá, že $v$ oblasti vysokoškolské výuky zde zatím rozhodně nejde o změnu systémovou. Pokud někde tato výuka směřuje $\mathrm{k}$ pochopení zásad nebo specifických projevů udržitelnosti, jedná se většinou o výsledek iniciativy jednotlivých vysokoškolských učitelů, nikoli o celý program nebo dokonce celoinstitucionální strategii. Z odpovědí na otázky položené $v$ rámci šetření je patrné, že značnou roli zde hrají sítě spolupráce především se západními zeměmi, a někdy také projektové financování, které inovace ve výuce, jež by souvisely s UR, vyžaduje. Jelikož obecně pedagogická činnost na vysoké škole $v$ tomto regionu nepracuje dostatečně $s$ principy pedagogiky ( $v$ profesním růstu vŠ učitelů není vyžadováno zvládnutí metod vysokoškolské výuky a souvisejících znalostí či dovedností; také reflexe cílů výuky, jejích procesů a využitých metod je spíše výjimkou), není ani věnována pozornost pedagogickým souvislostem VUR. Výsledkem pak je malá různorodost pedagogických přístupů užívaných ve výuce.

Co se týče kompetencí důležitých ve vzdělání pro udržitelný rozvoj, dobrou tradici zde mají postupy spadající do kategorie holistický př́stup. Jde především o systémové myšlení, které do výuky přinesla její „ekologizace" už v průběhu 80. let, která vyžadovala pochopení širších souvislostí mezi světem prírodním a lidskou kulturou. Ideové směry označované jako "myšlení budoucnosti”, jež zahrnují strategické úvahy i uvědomělé rozhodování o budoucích problémech či situacích, se zde také začínají prosazovat, prozatím ale především v prakticky orientovaných projektech, které mají technicky uchopitelná řešení. Je dále možno ř́ci, že nejvíce kompetencí, které popsali respondenti ve svých národních 
zprávách, spadá do znalostní domény, což je ve vysokoškolské výuce málo překvapivé. Naopak je povzbudivé, že kompetence jsou na této úrovni vzdělání pěstovány $\mathrm{i} v$ dalších doménách (učit se jednat; učit se žít společně; učit se být), zde však existují značné rozdíly mezi jednotlivými zeměmi.

Celkově Ize říci, že z hlediska uplatnění principů UR na vysokých školách je samotná forma vysokoškolské výuky (tedy pedagogické aspekty výuky) značně podceňovanou součástí praxe vysokých škol. To má pak dopad na rozvoj potřebných kompetencí, a to u samotných vysokoškolských učitelů, pravděpodobně se to však následně týká i studentů, pro které jsou často jejich učitelé modelovým vzorem.

\section{Seznam zkratek}

- EHK OSN - Evropská hospodářská komise OSN

- $\quad$ ESD - Education for Sustainable Development = VUR

- OSN - Organizace spojených národů

- UE4SD - projekt University Educators for Sustainable Development, viz http://www.ue4sd.eu.

- UNECE - United Nations Economic Commission for Europe - EHK OSN

- UR - udržitelný rozvoj

- VUR - vzdělání pro udržitelný rozvoj

- Vš - vysoké školy

\section{Poděkování}

Tento článek využívá informace získané v rámci projektu UE4SD (European Commission under the Life Long Learning Programme - Erasmus Academic Networks) jeho text vznikl v rámci projektu "Využití regionálních př́padových studií udržitelného rozvoje ve vysokoškolské výuce a pro tvorbu tzv. Open Educational Resources" (TD020400) financovaného Technologickou agenturou České republiky, jíž patří poděkování.

\section{Literatura:}

- Balazs, K., Faulkner, W., \& Schimank, U. (1995). Transformation of the Research Systems of Post-Communist Central and Eastern Europe: An Introduction. Social Studies of Science, 25(4), 613-632. Retrieved from http://sss.sagepub.com/cgi/doi/10.1177/030631295025004002 http://dx.doi.org/10.1177/030631295025004002

- Barton, A., \& Dlouhá, J. (2014) Examining the Transition Toward Sustainability in Higher Education in Central Europe. In Vávra, J., Lapka, M (Ed.), Curent Challenges of Central Europe: Society and Environment (pp. 44-67). Praha: UK, Filosofic- 
ká fakulta. Retrieved from http://www.ecoology.org/wp-content/uploads/Currentchallenges-of-CE-07.pdf

- Bednaříková, I. (2012). Měnící se role vysokoškolského učitele v kontextu společenských změn. Aula, 20(1), 136-149. Retrieved from http://www.csvs.cz/aula/clanky/Aula 02-2012 Bednarikova 136 149.pdf

- Buckler, C., \& Creech, H. (2014). Shaping the future we want: UN Decade of Education for Sustainable Development; final report. Routledge: UNESCO.

- COPERNICUS. Alliance, (2015). Rio +20 Teaty on Higher Education. . Retrieved from http://hetreatyrio20.com

- Dlouhá, J., \& Moldan, B. (2013) Sustainability in Higher Education: The Central and Eastern European Case. In M. Adomssent (Ed.), Higher Education for Sustainable Development in Central and Eastern Europe (pp. 13-32). Bad Homburg: Verlag fur Akademische Schriften.

- Dlouhá, J., \& Moldan, B. (2012) Sustianability in higher education: the Central and Eastern European case. In M. Barceló et al. (Eds.), Higher Education in the World 4. Higher education's Commitment to Sustainability: From Understanding to Action. GUNI Series on the Social Commitment of Universities. Global University (pp. 129-132). New York: Palgrave Macmillan.

- Kohoutek, J. (2009). Setting the stage: Quality assurance, policy change, and implementation. Implementation of the standards and guidelines for quality assurance in higher education in the central and East-European Countries-agenda ahead, 11-19.

- Kopnina, H. (2012). Education for sustainable development (ESD): the turn away from 'environment' in environmental education. Environmental Education Research, 18(5), 699-717. Retrieved from http://www.tandfonline.com/doi/abs/10.1080/13504622.2012.658028 http://dx.doi.org/10.1080/13504622.2012.658028

- Lozano, R., Ceulemans, K., Alonso-Almeida, M., Huisingh, D., Lozano, F. J., Waas, T., ... Hugé, J. (2015). ., 108, 1-18. Retrieved from http://linkinghub.elsevier.com/retrieve/pii/S0959652614009780 http://dx.doi.org/10.1016/j.jclepro.2014.09.048

- Lukman, R., Krajnc, D., \& Glavič, P. (2009). Fostering collaboration between universities regarding regional sustainability initiatives - the University of Maribor. Journal of Cleaner Production, 17(12), 1143-1153. Retrieved from http://linkinghub.elsevier.com/retrieve/pii/S0959652609000596 http://dx.doi.org/10.1016/j.jclepro.2009.02.018

- Lukman, R., Krajnc, D., \& Glavič, P. (2010). University ranking using research, educational and environmental indicators. Journal of Cleaner Production, 18(7), 619-628. Retrieved from http://linkinghub.elsevier.com/retrieve/pii/S0959652609003047 http://dx.doi.org/10.1016/j.jclepro.2009.09.015 
- Salecedo-Rahola, B., Mulder, K., et al., (2012). Sustainable Development in Higher Education. What has Europe got to offer?. Delft: Delft University of Technology. Retrieved from http://www.sdpromo.info

- Sibbel, A. (2009). Pathways towards sustainability through higher education. Int J of Sus in Higher Ed, 10(1), 68-82. Retrieved from http://www.emeraldinsight.com/doi/abs/10.1108/14676370910925262 http://dx.doi.org/10.1108/14676370910925262

- $\quad$ Sterling, S., Maxey, L., \& Luna, H. (2013). The sustainable university: Progress and prospects: Routledge.

- Štech, S. (1999) Teoretické přístupy k vysokoškolské pedagogice. In J. Vašutová et al. (Eds.), Vybrané otázky vysokoškolské pedagogiky (pp. 157-166). Praha: ÚVRŠ.

- Tilbury, D. (2011). Education for Sustainable Development: An Expert Review of Processes and Learning. Paris: UNESCO. Retrieved from http://unesdoc.unesco.org/images/0019/001914/191442e.pdf

- Tilbury, D., \& Mulà, I. (2009). Review of Education for Sustainable Development Policies from a Cultural Diversity and Intercultural Dialogue: Gaps and Opportunities for Future Action. Paris: UNESCO. Retrieved from http://unesdoc.unesco.org/images/0021/002117/211750e.pdf

- UE4SD (2014). Mapping opportunities for professional development of university educators in Education for Sustainable Development: A state of the art report across 33 UE4SD partner countries. Authors: Mader, M., Tilbury, D., Dlouhá, J., Benayas, J., Michelsen, G., Mader, C., Burandt, S., Ryan, A., Barton, A., Dlouhý, J., and Alba, D. Cheltenham: University of Gloucestershire.

- UE4SD (2015). Leading Practice Publication: Professional development of university educators on Education for Sustainable Development in European countries. Editors: Kapitulčinová, D., Dlouhá, J., Ryan, A., Dlouhý, J., Barton, A., Mader, M., Tilbury, D., Mulà, I., Benayas, J., Alba, D., Mader, C., Michelsen, G., Vintar Mally, K.. Praha: Charles University in Prague. Retrieved from http://www.ue4sd.eu/images/2015/UE4SD-Leading-Practice-PublicationBG.pdf

- $\quad$ UNECE (2005). UNECE Strategy on Education for Sustainable Development. . Retrieved from http://www.unece.org/environmental-policy/education-forsustainable-development/about-the-strategy-for-esd/the-strategy.html

- UNECE (2011). Learning for the future: Competences in Education for Sustainable Development, ECE/CEP/AC.13/2011/6. Retrieved from http://www.unece.org/fileadmin/DAM/env/esd/ESD Publications/Competences Pu blication.pdf

- Vašutová, J. (2002). Strategie výuky ve vysokoškolském vzdělávání. Praha: Univerzita Karlova v Praze, Pedagogická fakulta.

- Vašutová, J. (2012). University lecturers and students in new role in educational process. Česká kinantropologie/Czech kinanthropology, 16(2), 
- Waas, T., Hugé, J., Ceulemans, K., Lambrechts, W., Vandenabeele, J., Lozano, R., \& Wright, T. (2012). Sustainable Higher Education. Understanding and Moving Forward. status: Published. Understanding and Moving Forward. status: published.

- Wals, A. E. J. (2010). Between knowing what is right and knowing that is it wrong to tell others what is right: on relativism, uncertainty and democracy in environmental and sustainability education. Environmental Education Research, 16(1), 143-151. Retrieved from http://www.tandfonline.com/doi/abs/10.1080/13504620903504099 http://dx.doi.org/10.1080/13504620903504099 